\title{
ANALISIS SEMIOTIK PADA JURNALISTIK FOTO "Melihat Momen Unik Deklarasi Kampanye Damai idi Media Online Detik.com"
}

\author{
Arsa Widitiarsa Utoyo \\ Universitas Bina Nusantara \\ Email: arsa_w@binus.ac.id
}

\begin{tabular}{|c|c|}
\hline ARTICLE INFO & ABSTRACT \\
\hline $\begin{array}{l}\text { Keywords: } \\
\text { Photography; } \\
\text { Communication; Semiotic; } \\
\text { Journalistic }\end{array}$ & $\begin{array}{l}\text { Journalistic photos in online mass media are displayed with the aim of } \\
\text { strengthening and visualizing the contents of the news. Therefore, journalistic } \\
\text { photos in the newspaper have a role in involving feelings and arousing the } \\
\text { emotions of readers. This research aims to analyze on how a message icon be } \\
\text { known by its meaning both seen from the true meaning (denotative) and the } \\
\text { meaning implied in it (connotative). To find the meaning contained in journalistic } \\
\text { photographs, the author uses the semiotic approach. Semiotic analysis is a method } \\
\text { for analyzing and giving meanings it symbols contained in a message or text } \\
\text { symbol. The application if semiotics in intersexuality is an interaction between } \\
\text { texts and thoughts contained in the narrative. A safe and peaceful general election } \\
\text { discourse can be seen from the photo. }\end{array}$ \\
\hline
\end{tabular}

\section{PENDAHULUAN}

Komisi pemilihan umum menggelar acara deklarasi kampanye damai pemilihan umum 2019 yang diadakan pada hari minggu, 23 September 2018 di lapangan silang Monumen Nasional, Jakarta Pusat. Tujuan deklarasi kampanye tersebut untuk mensosialisasikan kepada seluruh partai pendukung hingga masyarakat mengenai pentingnya membuat kampanye yang damai, aman dan kondusif. Pada halaman detik.com yang dimuat hari Senin tanggal 24 September 2018 terdapat momen-momen yang unik dan menarik masyarakat seperti saat para pendukung Jokowi-Ma'ruf Amin dan Prabowo-Sandi terlihat mengenakan pakaian adat.

Selain mereka juga para pendukung kedua pasangan calon, para komisioner komisi pemilihan umum juga terlihat menggunakan pakaian adat ${ }^{1}$. Perkembangan media elektronik pada saat ini mengalami kemajuan yang sangat pesat, berbagai macam informasi yang menarik perhatian khalayak dan informasi yang semakin dinamis setiap harinya yang dikemas dalam bentuk berita maupun sebagai interaktif informasi yang mudah diterima oleh berbagai kalangan. Perkembangan informasi ini dituntut untuk memiliki mutu di dalam penyajian berita yang dapat dikemas secara informatif, beragam dan semenarik mungkin agar minat khalayak akan media electronik mudah untuk diserap berbagai kalangan dengan menggunakan berbagai macam tipe informasi yang tidak hanya dalam bentuk text tetapi dapat juga menggunakan bentuk visual yang berupa gambar dan foto.

Salah satu kelebihan yang dimiliki suatu gambar maupun foto pada media elektronik adalah kemudahan untuk dapat dicerna dan mudah diingat. Foto memiliki makna tersendiri yang mengandung permasalahan yang tengah terjadi dan berkembang dalam masyarakat. Foto dapat memberikan arti berbagai pemasalahan yang tengah terjadi dan berkembang dalam masyarakat seperti menyangkut isu politik, sosial, ekonomi, budaya dan lain sebagainya. Foto dapat juga menggambarkan berita secara tersirat, menggambarkan simbol-simbol yang ada di dalamnya. Berbagai macam pesan yang disampaikan kerap kali berkaitan dengan keberpihakan media dalam menyajikan suatu realitas atau berbagai isu sosial yang terjadi. www.detik.com merupakan salah satu surat kabar elektronik yang selalu menyajikan berita secara cepat dan actual, semua berita yang di informasikan selalu menyajikan foto beserta dengan naskah beritanya.

\footnotetext{
${ }^{1}$ https://news.detik.com/foto-news/d-4225750/melihat-lagi-momen-unik-deklarasi-kampanye-damai-di-monas/3\#share_top
} 
Melalui penelitian ini, penulis berusaha untuk bisa lebih memahami makna komunikasi yang terdapat di dalam sebuah foto jurnalistik yang disajikan oleh www.detik.com. Peneliti juga ingin mengkaji lebih jauh tentang pemahaman pembaca terhadap foto jurnalistik yang sering menghiasi di berbagai macam media khususnya media elektronik.

Foto jurnalistik mempunyai fungsi sebagai perpaduan maupun kombinasi antara teks berita yang disertakan dengan foto sehingga dapat menarik perhatian serta menimbulkan rasa ingin tahu dari pembaca ketika melihat berita tersebut. Dalam foto jurnalistik pada media elektronik, terdapat sebuah makna yang mengartikan sebuah komunikasi efektif antara wartawan dengan pembaca dikarenakan foto dapat dinilai mampu berbicara mewakili seribu Bahasa. Foto sendiri memiliki makna yang bersifat langsung (denotasi) dan tidak langsung (konotasi), yang berarti pesan yang akan disampaikan oleh foto secara keseluruhan atau secara visualisasi (objektif) dan sesuatu yang dihasilkan oleh unsurunsur yang terdapat di dalam foto tersebut sejauh bagaimana pemahaman kita membedakan unsurunsur tersebut (subjektif). Dengan adanya foto dan tulisan yang ditampilkan pada deklarasi kampanye damai pemilihan umum 2019 di www.detik.com pada hari Senin 24 September 2018, penulis meneliti foto maupun tulisan yang disajikan oleh www.detik.com. Selain itu penulis ingin mengetahui maksud dan tujuan dari berita deklarasi kampanye damai pemilihan umum 2019. Dimulai dari pemilihan judul, pemilihan foto, hingga penyampaian artikel yang ditampilkan. Foto jurnalistik sendiri merupakan satu penyampaian yang memiliki makna, sehingga memerlukan metode khusus untuk dapat memahami dan mengartikan foto jurnalistik tersebut.

Metode yang digunakan juga harus mampu menganalisis tanda-tanda visual yang terdapat pada foto tersebut, penulis melakukan penelitian dengan menggunakan pendekatan semiotic model Roland Barhtes dikarenakan sesuai dengan pengungkapan pemaknaan foto, dalam hal ini metode yang digunakan untuk menggali makna dibalik tanda-tanda yang terdapat pada foto jurnalistik yang terdapat pada pada deklarasi kampanye damai pemilihan umum 2019 di www.detik.com pada hari Senin 24 September 2018.

\section{TINJAUAN TEORETIS}

Berdasarkan latar belakang di atas, maka didapatkan rumusan masalah dalam penelitian ini adalah bagaimana makna foto jurnalistik pada deklarasi kampanye damai pemilihan umum 2019 di www.detik.com pada hari Senin 24 September 2018. Tujuan yang ingin dicapai untuk mengetahui makna foto jurnalistik pada pemberitaan deklarasi kampanye damai pemilihan umum 2019 yang diberitakan pada www.detik.com pada hari Senin 24 September 2018.

\subsection{Komunikasi Massa}

Komunikasi bersumber dari kata communis yang berarti sama yang dimaksud dengan sama makna [13]. Menurut De Vito komunikasi massa adalah komunikasi yang ditujukan kepada massa, kepada khalayak yang sangat luas atau banyak, komunikasi massa akan lebih mudah dan lebih logis bila didefinisikan menurut bentuknya seperti website, televisi, radio, surat kabar, majalah, film, buku dan pita [14]. Website sendiri mempunyai fungsi yang jauh lebih besar dari sekedar menyampaikan dan menyebarkan informasi dikarenakan merupakan refleksi dari masyarakat maupun keadaan sekitar. Website adalah suatu metode untuk menampilan informasi di internet, baik berupa teks, gambar, suara maupun video yang interaktif dan mempunyai kelebihan untuk menghubungkan (link) satu dokumen dengan dokumen lainnya (hypertext) yang dapat diakses melalui sebuah browser [8].

\subsection{Foto Jurnalistik}

Foto jurnalistik merupakan salah satu bidang di dalam fotografi yang mengkhususkan kepada proses penciptaan karya fotografi yang dianggap memliki nilai berita dan mampu menampilkannya kepada pembaca dengan tujuan tertentu melalui media massa [15]. Perbedaan jurnalistik foto dengan foto dokumentasi adalah foto-foto yang ditampilkan di dalam media massa adalah foto jurnalistik, sedangkan foto dokumentasi tidak. Tiga faktor utama yaitu rasa keingintahuan manusia yang merupakan naluri dasar, yang menjadi bahan kemajuan, pertumbuhan media massa sebagai media audio visual yang memuat tulisan dan gambar (termasuk gambar bergerak), kemajuan teknologi yang memungkinkan terciptanya kemajuan fotografi dengan pesat (termasuk perfilman dan video untuk pemberitaan). Jurnalistik foto dibedakan dari beberapa cabang fotografi lain 
seperti fotografi dokumentasi, street photography, atau fotografi selebritas, berdasarkan kualitas dari Ketepatan waktu (Timeliness) [9].

\subsection{Teori Semiotika}

Semiotika berasal dari bahasa Yunani: semeion, yang berarti tanda. Secara sederhana, semiotika didefinisikan sebagai teori tentang tanda atau sistem tanda. Sedangkan tanda atau sign adalah sesuatu yang memiliki makna, yang mengkomunikasikan pesan-pesan kepada seseorang. Menurut Aart Van Zoest, semiologi memiliki dua pendekatan yang dipelopori oleh Charles Sanders Peirce dan Ferdinand de Saussure.

Jika kita mengikuti Charles Sanders Peirce, maka semiotika tidak lain dari pada sebuah nama lain bagi logika, yakni "doktrin formal tentang tanda-tanda" (the formal doctrine of signs) sementara itu bagi Ferdinand de Saussure, semiotic atau semiologi adalah sebuah ilmu umum tentang tanda, "suatu ilmu yang mengkaji kehidupan tanda-tanda di dalam masyarakat" (a science that studies the life of sign withinsociety) [16].

Perbedaan pendekatan semiotik di antara keduanya adalah, bagi Peirce pendekatan semiotikanya lebih menekankan pada logika, sedangkan Saussure lebih menekankan pada linguistik. Sementara itu sosial dapat diartikan sebagai sesuatu yang berkaitan dengan interaksi manusia, atau dapat pula diartikan sebagai sesuatu yang berkaitan dengan masyarakat. Dengan kata lain, semiotika sosial adalah sebuah ilmu yang mempelajari sederetan objek, peristiwa, kebudayaan, dan lain-lain di tengah masyarakat sebagai sebuah tanda yang memiliki arti tertentu. Roland Barthes menyempurnakan teori semiotik milik Saussure yang hanya berhenti pada pemaknaan penanda dan petanda saja, Mengembangkan dua tingkatan pertandaan (two way of signification) yang memungkinkan untuk dihasilkannya makna yang juga bertingkat-tingkat, yaitu tingkat denotasi dan konotasi.

Denotasi adalah tingkat pertandaan yang menjelaskan suatu hubungan antara penanda dan petanda atau antara tanda dan rujukannya pada realitas yang dapat menghasilkan makna eksplisit, langsung dan pasti. Sedangkan konotasi adalah tingkat pertandaan yang menjelaskan hubungan antara penanda dan petanda yang didalamnya beroperasi makna yang tidak eksplisit, sehingga tidak langsung dan tidak pasti (artinya terbuka terhadap berbagai kemungkinan). Ia mampu menciptakan sebuah makan-makna lapis kedua, yang terbentuk ketika penanda dikaitkan dengan berbagai aspek yang psikologis seperti perasaan, emosi atau keyakinan [17].

Dalam perkembangannya, semiotika melahirkan berbagai aliran yang dipengaruhi oleh perbedaan paradigma. Menurut Theo van Leeuwen, dalam semiotika sosial dibahas hal-hal berikut. Sebagaimana sempat disinggung di atas, "sumber semiotik", adalah sebuah tindakan atau artefak yang digunakan dan tercipta dalam sebuah peristiwa komunikasi. Misalnya, ekspresi wajah, gestur, pensil, kertas, atau komputer. Sumber-sumber semiotik tidak terbatas pada perkataan, tulisan, atau gambar, namun hampir semua hal yang memiliki makna secara sosial dan kultural, Dalam semiotik, tanda adalah sesuatu yang menggambarkan sesuatu yang lain, yang terdiri atas dua materi dasar yaitu 'ekspresi' dan 'konten'. Hubungan antara materi ekspresi dan konten berjalan dengan dinamis, bergantung pada perspektif pemakna. Oleh karena itu, tanda tidak pernah sepenuhnya lengkap, karena memerlukan adanya subjek penginterpretasi dan juga konteks. Tandalah menghadirkan kekhususan serta mendukung relasirelasi sosial di tengah-tengah masyarakat. Di dalam tanda ada sesuatu yang tersembunyi dan diwakilkan, bukan merupakan tanda itu sendiri. Tanda inilah yang mengandung makna.

\subsection{Denotasi dan Konotasi dalam Foto}

Di dalam "The Photographic Message", Roland Barthes tiga tahapan dalam membaca foto yang bersifat konseptual, yaitu: perseptif, konotasi kognitif, dan etis-deologis. Dimana pada tahap perseptif merupakan tahap transformasi gambari menuju ategori verbal atau verbalisasi gambar yang bersifat imajinatif. Pada tahap konotasi kognitif merupakan tahap pengumpulan dan upaya untuk menghubungkan unsur-unsur sejarah dari dari analogi denotasi ke dalam imajinasi paradigmatic. Sehingga menghasilkan pengetahuan kultural sangat menentukan.

Pada tahap etis-ideologis merupakan tahap pengumpulan berbagai penanda yang siap "dikalimatkan" sehingga motifnya dapat ditentukan. Dimana pada tahap ketiga tersebut merupakan 
tahapan-tahapan konseptual atau diskursif untuk dapat menentukan wacana suatu foto. Dengan demikian objektifitas pesan foto dapat diamati dan diukur. Di dalam salah satu essainya konotasi didalam foto dapat timbul melalui enam prosedur yang dikategorikan menjadi dua. Pertama rekayasa secara langsung dapat mempengaruhi realitas itu sendiri meliputi trick effect, pose, dan pemilihan objek, sedangkan yang kedua rekayasa yang masuk dalam wilayah 'estesis' yang terdiri dari photogenia, aestheticism dan syntax. Sistem denotasi merupakan system penandaan tingkat pertama, yang terdiri dari rantai penanda dan petanda sehingga mampu mempunyai hubungan dengan materialitas. Sedangkan untuk penanda tingkat kedua rantai penanda atau petanda lain yang menjadi penanda dan seterusnya.

Menurut Roland Barthes pada tingkat denotasi linguistic menghadirkan konvensi atau kodekode sosial yang bersifat eksplit, yakni kode-kode yang makna tandanya segera tampak pada permukaan, sebaliknya pada tingkat konotaso linguistic menghadirkan kode-kode yang makna tandanya bersifat implisit, yaitu system kode yang tandanya bermuatan makna-makna tersebunyi. Makna tersebunyi ini yang menurut Barthes merupakan Kawasan dari ideologi maupun metologi, padangan strukturalnya, bahwa bentuk pertandaan denotatif, pada akhirnya harus mengandung di dalam dirinya penandaan dan makna ideologi [7].

\section{METODE PENELITIAN}

Menurut Lincoln dan Guba, penelitian ini menggunakan metode kualitatif dan diharapkan mampu menangkap berbagai informasi kualitatif deskriptif yang mendasari perwujudan sebuah makna dari gejala-gejala sosial di dalam masyarakat [12]. Penelitian deskriptif menggunakan pengamatan dengan memaparkan suatu peristiwa, tidak mencari maupun menjelaskan hubungan tidak menguji hipotesa atau membuat prediksi [18].

Sumber data yang digunakan adalah sumber data primer. Data primer adalah suatu objek ataupun asli yang berupa material mentah dari pelaku utamanya yang disebut sebagai in first hand information. Data-data yang dikumpulkan di sumber primer ini berasal dari situasi langsung yang aktual ketika suatu peristiwa itu terjadi. Data penelitian yang diperoleh langsung dari penelitian melalui cara observasi terhadap objek penelitian foto jurnalistik pada foto jurnalistik yang diabadikan oleh Pradita Utama pada saat acara deklarasi kampanye damai pemilihan umum 2019. Selain itu data yang digunakan adalah sumber data sekunder. Sumber Data Sekunder adalah sumber data yang dikumpulkan berasal dari tangan ke dua atau sumbersumber lain yang telah tersedia sebelum penelitian ini dilakukan. Data sekunder umumnya berupa bukti, catatan atau laporan historis yang telah tersusun dalam arsip (data dokumenter) yang sudah dipublikasikan yaitu berupa foto dan berita.

Dalam penelitian kualitatif ini menggunakan teknik sampling, yaitu purposive sampling. Purposive sampling adalah teknik pengambilan sampel sumber data dengan pertimbangan tertentu yakni sumber data dianggap paling tahu tentang apa yang diharapkan, sehingga mempermudah Peneliti menjelajahi obyek atau situasi sosial yang sedang diteliti, yang menjadi kepedulian dalam pengambilan sampel penelitian kualitatif adalah tuntasnya pemerolehan informasi dengan keragaman variasi yang ada, bukan pada banyak sampel sumber data.

Teknik observasi digunakan dalam penelitian ini. Teknik Observasi merupakan teknik pengumpulan data yang mempunyai ciri yang spesifik bila dibandingkan dengan teknik yang lain yaitu wawancara dan kuesioner. Karena observasi tidak selalu dengan obyek manusia tetapi juga obyek-obyek yang lain. Observasi merupakan suatu proses yang kompleks, suatu proses yang tersusun dari berbagai proses biologis dan psikologis. Dua diantara yang terpenting adalah proses- proses pengamatan dan ingatan. Observasi yang digunakan pada penelitian ini yaitu observasi tidak langsung. Observasi tidak langsung adalah observasi yang dilakukan tidak pada saat berlangsungnya suatu peristiwa yang diteliti, misalnya melalui film, rangkaian slide, atau rangkaian foto [10].

Teknik triangulasi digunakan pula dalam penelitian ini untuk melihat keabsahan data yang [11]. Teknik ini merupakan pemeriksaan keabsahan data yang mampu memanfaatkan sesuatu yang lain, sehingga bisa untuk menunjuk pada upaya membandingkan temuan data yang sudah diperoleh dengan menggunakan metode tertentu. 


\section{HASIL PENELITIAN DAN PEMBAHSAN}

\subsection{Foto Jurnalistik Deklarasi Kampanye Damai Pemilihan Umum 2019}

Objek penelitian ini adalah foto jurnalistik deklarasi kampanye damai pemilihan umum 2019 di www.detik.com pada hari Senin 24 September 2018.



Sumber foto:

https://news.detik.com/foto-news/d-4225750/melihat-lagi-momen-unik-deklarasi-kampanye-damai-

\subsection{Fotografi Jurnalistik}

di-monas/1\#share_top

Bahasa merupakan salah satu alat komunikasi. Fotografi dapat dipadankan juga Bahasa. Dikarenakan fotografi berfungsi sebagai alat untuk berkomunikasi, layaknya kata- kata yang digunakan oleh seorang penulis untuk mengungkapkan apa yang diinginkannya. Melalui suatu bahasa gambar tersebut, maka seorang fotografer menyampaikan pesan secara visual mencakup berbagai jenis pesan, yaitu berupa penyampaian pesan, ide, gagasan, visi, sikap fotografer dan penikmatnya. Dasar dari foto jurnalistik adalah gabungan antara gambar dan kata. Keseimbangan data tertulis pada teks gambar adalah mutlak. Caption foto atau keterangan gambar sangat membantu gambar untuk memberikan informasi secara lengkap kepada masyarakat atau pembaca.

Deklarasi kampanye damai pemilihan umum 2019 yang diadakan oleh kominisi pemilihan umum (KPU) pada hari minggu tanggal 23 September 2018 dibuka dengan pembacaan deklarasi kampanye damai yang berisi:

"Kami peserta Pemilu tahun 2019, berjanji: Satu mewujudkan pemilu yang langsung, umum, bebas, rahasia, jujur, dan adil,"”.

Yang di ucapkan oleh Ketua KPU Arief Budiman diikuti dengan calon presiden dan wakil presiden dan ketua umum partai politik di lapangan moumen nasional Jakarta. Menurut beliau tujuan dari deklarasi kampanye damai ini agar peserta pemilu melakukan pemilihan dengan damai, tertib, menjauhi politik uang, sara, dan penggunaan hoax.

Teks deklarasi kampanye damai pemilu 2019 selengkapnya berisi:

Kami peserta Pemilu tahun 2019, berjanji:

Satu, mewujudkan Pemilu yang langsung, umum bebas, rahasia, jujur dan adil.

Dua, melaksanakan kampanye pemilu yang aman tertib, damai, berintegritas, tanpa hoax, politisasi SARA, dan politik uang.

Tiga, melaksanakan kampanye berdasarkan peraturan perundang-undangan yang berlaku.

Jakarta, 23 septermber 2018.

\subsection{Makna Denotasi}

Dalam foto ini terlihat keakraban calon presiden, calon wakil presiden, petinggi partai dan juga para pendukung yang sesuai dengan maksud dan tujuan dari deklarasi kampanye damai pemilihan umum 2019, hal ini diperlihatkan dari raut muka maupun kegembiaraan

\footnotetext{
${ }^{2}$ https://news.detik.com/berita/4224771/isi-deklarasi-kampanye-damai-pemilu-2019-tanpa-hoax-dan-sara
} 
yang tercermin dari para peserta. Komposisi foto yang diambil secara horizontal dengan jarak pengambilan objek menggunakan long shoot dan angle dibuat eye level.

\subsection{Makna Konotasi}

Trick Effect

Tidak ada trick effect yang digunakan pada foto jurnalistik deklarasi kampanye damai pemiluhan umum 2019. Foto jurnalistik tersebut diambil secara natural tanpa ada upaya tindakan memanipulasi foto. Pada foto tersebut tidak tampak sedikitpun penambahan, pengurangan maupun mengubah foto hingga menjadi sebuah gambaran yang sama sekali lain hingga dapat menjadikan arti yang lain. Dengan artian bahwa fotografer dari www.detik.com tidak menggunakan trick effect dalam pembuatan atau penyampaian foto berita. Fotografer ingin menunjukkan kejadian dan keadaan deklarasi kampanye damai tersebut dengan apa adanya sesuai dengan kenyataan.

Pose

Terlihat objek utama yaitu calon presiden dan wakil presiden beserta dengan para petinggi partai pendukung. Pose calon presiden dan wakil presiden tanpak terlihat akrab dan bersahabat. Sedangkan jika melihat dibelakang mereka tampak para petinggi partai juga terlihat sumringah.

Objek

Objek utama dari foto ini adalah calon president dan wakil presiden yang sedang menghadiri acara deklarasi kampanye damai pemilihan umum 2019. Objek pendukung adalah para petinggi partai dan warga masyarakat. Fotographer ingi memperlihatkan objek utama dan situasi di sekitar objek utama.

Photogenia

Teknik yang digunakan adalah frezzing atau bisa disebut juga membekukan gambar yang bertujuan agar gambar tidak gerak. Dapat terlihat dari objek yang tersenyum.

Aestethism

Format gambar horizontal, pengambilan gambar eye level, jarak pengambilan objek long shoot dan penempatan objek utama di tengah.

Sintaksis

Foto tersebut di ambil pada saat deklarasi kampanye damai pemilihan umum 2019 tanggal 24 September 2018 diambil oleh fotografer jurnalistik bernama Pradita Utama dari berita online www.detik.com.

Makna Keseluruhan

Di dalam foto jurnalistik tersebut dapat dimaknai bahwa, pesan dan kesan yang disampaikan oleh fotografer sesuai dengan tema dari acara deklarasi kampanye damai 2019 yang bertujuan untuk menciptakan pemilihan umum dengan damai, tertib, menjauhi politik uang, sara, dan penggunaan hoax.

\section{SIMPULAN}

Sebuah foto mengandung sebuah makna, pada dasarnya foto jurnalistik di harian online www.detik.com tentang deklarasi kampanye damai pemilihan pemilu 2019 pada hari minggu 24 September 2018 adalah representasi aktual harian online www.detik.com terhadap arti dan makna acara deklarasi kampanye damai pemilihan umum 2019 yang di selengarakan oleh KPU di Jakarta. Foto jurnalistik di harian online www.detik.com merupakan sebuah informasi visual $w w w$.detik.com dalam menyajikan sebuah gambaran peristiwa keakraban dan 
perdamaian, yang ditujukan kepada pembacanya yang diharapkan mampu menggugah emosi pembaca untuk untuk merasakan pemilihan umum 2019 yang aman dan damai.

Dari pemuatan foto jurnalistik yang diangkat di harian www.detik.com tentang acara tersebut terlihat adanya pesan dan kesan yang tercermin dari semua orang yang dating pada hari itu dan juga merupakan cerminan yang sesuai dengan tema acara deklarasi damai, sehingga khalayak pembaca dapat mengaktualisasi keadaan sebenarnya yang disampaikan oleh www.detik.com sebagai sebuah gambaran visual untuk melihat langsung acara tersebut lebih dekat melalui foto jurnalistik yang diangkat dari harian online www.detik.com. Dalam teknik pengungkapan pesan, foto-foto jurnalistik karya jurnalistik www.detik.com lebih mengandalkan kekuatan visual (gambar) sebagai suatu kekuatan penyampaian pesan. Karena bahasa gambar lebih universal dan dapat dipahami siapapun tanpa adanya batas-batas pemahaman kebahasaan.

\section{DAFTAR PUSTAKA}

1. Witjaksana, Gunawan. 2009. Pokok-pokok Pikiran Dalam Metodologi Penelitian Kualitatif. Semarang: Ilmu Komunikasi USM

2. Sutopo, HB. 2006. Metode Penelitian Kualitatif. Surakarta: UNS Press.

3. Silalahi, Ulber. 2006. Metode Penelitian Sosial. Bandung: Unpar Press.

4. Barthes, Roland. 2012. Elemen - Elemen Semiologi, Yogyakarta: Jalasutra

5. Budiman, Kris. 2003. Semiotika Visual. Yogyakarta: Penerbit Buku Baik

6. Manajemen Periklanan Konsep Dan Aplikasinya Di Indonesia. Jakarta: PT Pustaka Utama Kurniawan. 2001.

7. Piliang, Yasraf Amir, 2003. Hipersemiotika Semiotika Tafsir Cultural Studies atas matinya makna, Bandung : Jalasutra.

8. Yuhefizar, Mooduto, \& Hidayat, R. 2009. Cara Mudah Membangun Website Interaktif Menggunakan Content Management System Joomla Edisi Revisi. Jakarta: PT Elex Media Komputindo

9. Soelarko, R. M., 1985. Pengantar Foto Jurnalistik, Bandung : PT. Karya Nusantara.

10. Sutrisno Hadi, Metodologi Research 2, Andi Offset, Yogyakarta, 2004

11. Moleong, Lexy. 2011. Metode Penelitian Kualitatif: Edisi Revisi. Bandung: PT. Remaja Rosdakarya

12. Bungin, Burhan. 2009. Penelitian Kualitatif. Jakarta: Kencana Prenada Media Group.Suranto.

13. Effendy, Uchjana Onong. 2005. Ilmu Komunikasi Teori dan Praktek. Bandung:Remaja Rosdakarya

14. Nurudin. 2004. Komunikasi Massa. Cespur: PT. Remaja Rosda Karya.

15. Soedjono, Suprapto. 2007. Pot-Pourri Fotografi. Jakarta : Trisakti

16. Sobur, Alex. 2006. Semiotika Komunikasi. Bandung: PT. Remaja Rosdakarya.

17. Kurniawan. 2001. Semiologi Roland Barthes, Magelang: Penerbit Yayasan Indonesiatera

18. Rakhmat, Jalaluddin. 2004. Metode Penelitian Komunikasi. Bandung: Remaja Rosdakarya.

\section{Jurnal}

1. Sebastian Dimas Triasmoro, Semiotika

2. Februari 2014 dan 23 Februari 2014) E- Journal Komunikasi, Tahun 2014 Universitas Atma Jaya, Yogyakarta.

\section{Sumber lain:}

1. https://news.detik.com/berita/4224771/isi-deklarasi-kampanye-damai-pemilu-2019-tanpa-hoaxdan-sara

2. https://news.detik.com/foto-news/d-4225750/melihat-lagi-momen-unik-deklarasi-kampanyedamai-di-monas/3\#share_top 